\title{
SPECIALLY PROTECTED NATURAL TERRITORIES OF ROSTOV REGION FEDERAL VALUE AND THEIR ROLE IN CONSERVATION OF NATURAL BIODIVERSITY
}

\author{
(C) Alexander D. Lipkovich
}

\author{
State natural biosphere reserve "Rostovsky" \\ Rostov-on-Don, Russian Federation \\ science-almanac@mail.ru
}

The role of specially protected natural areas (SPNA) of the federal significance of the Rostov Region $(\mathrm{RR})$ in the conservation of natural biodiversity is analyzed in this article. These are the state nature reserve "Rostovsky" (SNBR "Rostovsky") and the state natural reserve of federal significance "Tsimlyansky" (wildlife area "Tsimlyansky"). The SNBR "Rostovsky" was established in 1995, consists of 4 cluster divisions, has an area of 9.5 thousand hectares. The strictly reserved territory and 74,3 74,3 thousand hectares of preservation. Flora includes 503 species of vascular plants. Fauna of insects - 1568 species, spiders - 206. Terrestrial vertebrates: Amphibians - 3 species; reptiles - 10, birds - 258, mammals - 34. The "Tsimlyansky" reserve has an area of 35 thousand hectares. Here the most numerous nesting grouping of the Whitetail eagle in the $\mathrm{RR}$ is recorded, counting more than 30 breeding pairs. Nest colonies of common cormorant, number up to 5000 pairs. The elk, European deer, roe deer, wild boar, a number of species of birds, included in the Red Book of the RF and the RR, inhabit there. SPNA of RR federal significance successfully fulfill the tasks assigned to them on preservation natural biodiversity, maintenance and reproduction of rare population species of plants and animals, and are the source of such species settlement to adjacent territories.

Key words: state reserve, wildlife area, biodiversity preservation, flora, fauna.

\section{[А.Д. Липкович Особо охраняемые природные территории федерального значения ростовской области и их роль в сохранении природного биоразнообразия]}

Анализируется роль особо охраняемых природных территорий (ООПТ) федерального значения Ростовской области (РО) в сохранении природного биоразнообразия. Таковыми являются государственный природный заповедник «Ростовский» (ГПБЗ «Ростовский») и государственный природный заказник федерального значения «Цимлянский» (заказник «Цимлянский»). ГПБЗ «Ростовский создан в 1995 году, состоит из 4-х кластерных участков, имеет площадь 9,5 тыс. га. Собственно заповедной территории и 74,3 тыс. га охранной зоны. Флора насчитывает 503 вида сосудистых растений. Фауна насекомых - 1568 видов, пауков - 206. Наземные позвоночные: Земноводные - 3 вида; пресмыкающиеся - 10, птицы - 258, млекопитающие - 34 Заказник «Цимлянский» имеет площадь 35 тыс. га. Здесь отмечена самая многочисленная гнездовая группировка орлана белохвоста в РО, насчитывающая более 30 гнездовых пар. Гнездовые колонии большого баклана, насчитывают до 5000 пар. Обитают лось, европейский олень, косуля, кабан, ряд видов птиц, внесенных в Красную книгу РФ и РО. ООПТ федерального значения РО успешно выполняют возложенные на них задачи по сохранению природного биоразнообразия, сохранению и воспроизводству популяций редких видов растений и животных и являются источником расселения таких видов на сопредельные территории.

Ключевые слова: государственный заповедник, заказник, сохранение биоразнообразия, флора, фауна.

Alexander D. Lipkovich - candidate of biological studies, associate director on science of State natural biosphere reserve "Rostovsky". Rostov-on-Don, Russian Federation

Липкович Александр Давидович - кандидат биологических наук, заместитель директора по науке Ростовского заповедника, сотрудник Ростовского зоопарка, Ростов-на-Дону, Россия.

Conservation of natural biodiversity is one of the main tasks of Russia state nature reserves. Established in 1995, the reserve "Rostov" is located on the territory, historically experiencing significant anthropogenic loads in the form of pasturage, partly plowing and 
planting forest belts area of 9.5 thousand hectares. In course of time, almost all the forest belts withered, leaving behind either solitary trees or dry stumps. Plant formation, thinned with pasturage, is restored owing to natural biocenosis properties to self-regeneration under load removal, led to their deformation. The strict protection regime, maintained during the existence of the reserve, made it possible to bring steppe sites phytocenoses to the stable state with populations of rare plant species. The protection zone of the reserve has an area of 74,3 thousand hectares and serves as a buffer between the protected area and the lands of intensive agricultural use. The control of nature use in the buffer zone allows limiting the degree of pasture load and its negative consequences for the vegetation cover.

According to the reserve flora inventory and its conservation zone, there are now recorded the growth of 503 species of higher vascular plants. The growth of 15 species included in the Red Data Book of the Rostov Region is registered (RR).

For a species such as the heart semirary, the population of which is known on the northern shore of Lake Gruzskoye, the conservation zone of the reserve is the only place of growth in the RR. This is the only place in Russia where the population of this species is under protection. For the Regelovsky bow, the conservation zone of the reserve is one of two growth famous places in the RR. In addition, there are concentrated the largest population of the tulip Schrenk, the killer whale, bellevali Sarmatian in the RR. All this makes the flora and fauna of the reserve and its protection zone unique and one of the key places in the preservation of the natural floral diversity.

The fauna of insects totals 1568 species, attributed to 12 orders and 92 families [1]. Among them, 30 species included in the Red Book of the Russian Federation. In the fauna of spiders, 206 species from 26 families are registered [6] Fauna of terrestrial vertebrates includes:

Amphibians - 3 species;

Reptiles - 10 species. From them in RB RR - 6 [4];

Birds - 258 species. From them in RB RR - 33 [3];

Mammals - 34 species. From them in RB RR - 3 [2].

At present, the inventory of the flora and fauna of the territory under consideration is far from conclusion. But the already available data make it possible to speak with confidence about the extremely important role of the reserve and its conservation zone in preserving the natural biodiversity of the region. During the operating time regime of the reserve and its conservation zone, the population of rare nesting species of steppe birds (little bustard, demoiselle crane) is increased, long-legged buzzard and white-tailed eagle began to nest.

Colonial water birds nest on the island of "Zalivnoi". Curly pelicans significantly increased the number of single pairs in 2008 to more than 20 pairs in 2016 . The nesting of pink pelicans was for the first time reliably recorded in Rostov region in 2015. Great blackheaded gull, species, entered in the red list of RF and RR, nests at the island "Zalivnoi" from 2011. The number of this species in breeding comprised 100-120 pairs in 2011. In 2016, more than 700 nests were taken into account. And previously a single colony was divided into 3 sub-colonies. Thus, for 6 years there was a sevenfold increase in the nesting abundance of a rare species.

The number of some species, using the reserve territory and its preservation during migrational stops, is growing. Thus, the glossy ibis flocks in 10-15 animal units were observed at the freshwater bodies in 2008-2010. More than 300 birds of this type were held during two months in the reserve preservation in 2015-16. At the same time, for reasons of a natural character, migratory places of claiks and globally rare red-breasted geese migratory stops slightly changed. This led to a significant decrease in their seasonal numbers in the territory under consideration. The number of free-living horses on the reserved island "Vodnyi" has been regulated since 2012. According to the specialists recommendations, 
their numbers are maintained at 150-170 individuals (against more than 400 in 2010). This led to the activation of regenerative processes in steppe phytocenoses. The state of the vegetation cover has significantly improved. Meetings of gray partridges flocks, previously avoided spaces with severely degraded vegetation, on the island in 2016 can serve as indicator of this. Biological diversity is prone to natural fluctuations. The dynamics of the species composition of birds is monitored by the researchers. So in recent years, new species for the reserve and its conservation zone have been noted: bewicks swan, black vulture, pine bunting. The number of mammal population depends on natural reasons. The number hesitations of the most massive rodent - field vole affect the beasts condition miophags: birds of prey, owls, ordinary fox, corsac and others. In 2014 the peak of these rodents number led to the extraordinary concentration of marsh owl nidification. The maximum number of eggs in the eagle owl layings was noted at that year.

In 2016, for natural reasons, the number of foxes decreased sharply. This, as a result of a decrease in the level of predatory press, led to a marked increase in populations of gray partridge and European hare. In general, it can be noted that in the reserve and its buffer zone, there are stable populations of a number of rare plant and animal species. The dynamics of the mass species number depends mainly on the nature reasons and is monitored by the staff of the scientific department, which is consistent with the goals and objectives of the reserve. The status of biological diversity and its dynamics are under constant control of the scientific department of the reserve. The results of observations and monitoring are outlined in many publications. More than 200 scientific articles are published, 14 books "Annals of nature" are prepared, 7 issues of scientific "Writings" of the reserve are published.

Successes in preserving natural biodiversity are based on the daily hard work of the reserve protection department. Indicators of this work are the prevention of steppe fires and the suppression of violations of the protected regime. Despite extremely unfavorable weather conditions, for more than 10 years no steppe fire has been allowed on the protected area. Regular work is being done on the arrangement of fire breaks, the creation and maintenance of water intake sites, the creation and repair of fire bands, the organization of operational duty during a fire hazardous period. Regular work is being done on the fire breaks arrangement, the creation and maintenance of water intake sites, the creation and repair of fire bands, the organization of operational duty during a fire hazardous period.

In the maintenance of the protected regime, an important role is played by timely violations detection, drafting protocols and bringing to completion of offenses cases. 1121 violations of environmental legislation were educed and suppressed during the existence of the reserve on the reserve territory and its protection zone. The activities of the Environmental Education Department play an important role in the prevention of the protection regime violations. Creation of the reserve positive image, providing support for the ideas of nature conservation by wide sections of the population is a prerequisite for the conservation of its nature protection functions. The reserve actively participates in the development of ecological tourism. This is evidenced by data on the number of visitors to ecological trails: in 2010 - 2911 people, in 2016 - 13098. It has become traditional to hold in the protected area of the reserve a festival of ecological tourism "Vospetaya Step" [5].

It can be stated that the Rostov reserve successfully fulfills the tasks assigned to it to conserve natural biodiversity, preservation and reproduction of rare plant and animal species populations, and considers to be the source of such species settlement to adjacent territories. The state natural reserve of federal significance "Tsimlyansky" is located on the Kuchugury island in Tsimlyansky administrative district. Its area is 35 thousand hectares. These are spaces of ridge-hilly sands with separated forest stand of birch-aspen forests, groves of poplars and willow trees along the coast of the reservoir. The reserve is inhabit- 
ed by populations of elk, European deer, roe deer, wild boar. Pheasant, gray partridge, European hare are numerous. The most numerous group of white-tailed eagle nidicolous group, counting more 30 nidicolous pairs, European oyster catcher, stone curlew, little bustard, stilt, eagle owl resides there. The most numerous nesting colonies in the region of large cormorant, numbering up to 5000 pairs, numerous colonies of gray, large and small white herons are on the territory of the reserve. The coastal part of the reserve is the place of water birds migratory stops: swans, geese, many species of ducks. A large population of a patterned stance, introduced in the CC RD, inhabits here.

\section{Лumepamypa}

1. Арзанов Ю.Г., Пришутова З.Г., Полтавский А.Н., Набоженко М.В., Шохин И.В., Хачиков Э.А. Видовой состав фауны насекомых заповедника «Ростовский» // Экосистемный мониторинг долины Западного Маныча: итоги и перспективы Труды государственного природного биосферного заповедника «Ростовский». Вып. 6. Ростов-на-Дону, 2016.

2. Брагин А.Е., Липкович А.Д. Аннотированный список млекопитающих государственного природного биосферного заповедника «Ростовский», его охранной зоны и сопредельных территорий//Биоразнообразие долины Западного Маныча. Труды государственного природного биосферного заповедника «Ростовский». Вып. 5. Ростов н/Д, 2012.

3. Липкович А.Д. Аннотированный список птиц Государственного природного биосферного заповедника «Ростовский», его охранной зоны и сопредельных территорий. Часть 2. Воробьинообразные // Экосистемный мониторинг долины Западного Маныча: итоги и перспективы Труды государственного природного биосферного заповедника «Ростовский». Вып. 6. Ростов-на-Дону, 2016.

4. Липкович А.Д. Новые и редкие виды наземных позвоночных в фауне государственного природного биосферного заповедника «Ростовский»: находки 20082010гг. // Мониторинг природных экосистем долины Маныча. Труды ФГУ ГПБЗ «Ростовский». Вып. 4. Ростов н/Д, 2010.

5. Медянникова Н.М., Добрицкая В.В. Экологические акции и мероприятия в заповеднике «Ростовский»// Экосистемный мониторинг долины Западного Маныча: итоги и перспективы Труды государственного природного биосферного заповедника «Ростовский». Вып. 6. Ростов-на-Дону, 2016.

6. Пономарев A.B. Пауки (Arachnida: Aranei) заповедника «Ростовский»: кадастр видов и особенности фауны// Мониторинг природных экосистем долины Маныча. Труды ФГУ ГПБЗ «Ростовский». Вып. 4. Ростов н/Д, 2010.

\section{References}

1. Arzanov Yu.G., Prishutova Z.G., Poltavsky A.N., Nabozhenko M.V., Shokhin I.V., Khachikov E.A. Fauna species composition of insects of the reserve "Rostovsky"/l Ecosystem monitoring of the Western Manych valley: results and prospects Writings of the state natural biosphere reserve "Rostovsky". No 6. Rostov-on-Don, 2016.

2. Bragin A.E., Lipkovich A.D. Annotated list of mammals of the state natural biosphere reserve "Rostovsky", its guard zone and adjacent territories // Biodiversity of the Western Manych valley. Writings of the state natural biosphere reserve "Rostovsky". No 5. Rostov-on-Don, 2012. 
3. Lipkovich A.D. Annotated list of birds of the State Natural Biosphere Reserve "Rostovsky", its guard zone and adjacent territories. Part 2. Perching birds // Ecosystem monitoring of the Western Manych valley: results and prospects Writings of the state natural biosphere reserve "Rostovsky". No 6. Rostov-on-Don, 2016.

4. Lipkovich A.D. New and rare species of terrestrial vertebrates in the fauna of the state natural biosphere reserve "Rostovsky": findings of 2008-2010// Monitoring of natural ecosystems in the Manych valley. Writings of FSI SNBR "Rostovsky". No 4. Rostov-n/D, 2010.

5. Medyannikova N.M., Dobritskaya V.V. Ecological actions and activities in the reserve "Rostovsky" // Ecosystem monitoring of the Western Manych valley: results and prospects Writings of the state natural biosphere reserve "Rostovsky". No 6. Rostov-on-Don, 2016.

6. Ponomarev A.V. Spiders (Arachnida: Aranei) of the reserve "Rostovsky": species cadastre and fauna features // Monitoring of natural ecosystems in the Manych valley. Writings of FSI SNBR "Rostovsky". No 4. Rostov-n/D, 2010. 